\title{
Macroeconomic Determinants of Air Transportation: A VAR Analysis on Turkey
}

\author{
Havayolu Taşımacılığının Makroekonomik Belirleyicileri: Türkiye Üzerine \\ Bir VAR Analizi
}

\author{
Kasım KİRACI* \\ Ünal BATTAL**
}

\begin{abstract}
The aim of this study is to investigate the relationship between air transport and macroeconomic variables for the 1983-2015 period in Turkey, by using the VAR analysis. Three key indicators of air transport were used in the study. These were domestic passengers, international passengers and international cargos. In this study, three different models were created using indicators of air transport, including macroeconomic variables assumed to be related to them. In the first model, the relationship between domestic passenger demand and per capita gross domestic product (GDP), interest rate and consumer price index (CPI) was examined. In the second model, the relationship between international passenger demand and gross domestic product (GDP), interest rate and consumer price index (CPI) was examined. In the third model, the relationship between international cargo demand and gross domestic product (GDP), foreign trade volume, industrial production index and foreign direct investment amount was investigated. The results of the study show that per capita income, gross domestic product and consumer price index variables for domestic and international passenger demand are quite significant. In the case of International cargo demand, gross domestic product and industrial production index variables were observed to be influential.
\end{abstract}

Keywords: Air transport, Macroeconomic variables, VAR analysis

$\ddot{O} z$

Bu çalışmanın amacı, Türkiye'de havayolu taşımacılı̆̆ı ile makroekonomik değişkenler arasındaki ilişkinin 1983-2015 dönemi için VAR analizi kullanılarak incelenmesidir. Çalışmada, havayolu taşımacılığına ilişkin üç temel gösterge kullanılmıştır. Bunlar; iç hat yolcu, dış hat yolcu ve dış hat kargo şeklinde sıralanmaktadır. Çalışma kapsamında, havayolu taşımacılığına ait göstergeler kullanılarak, bunlarla ilişkili olduğu varsayılan makroekonomik değişkenlerin dâhil edildiği üç farklı model yaratılmıştır. Birinci modelde iç hat yolcu talebi ile kişi başına gayrisafi yurtiçi hâsıla (GSYH), faiz oranı ve tüketici fiyat endeksi (TÜFE) arasındaki ilişki incelenmiştir. İkinci modelde diş hat yolcu talebi ile gayrisafi yurtiçi hâsıla (GSYH), faiz oranı ve tüketici fiyat endeksi (TÜFE) arasındaki ilişki ele alınmıştır. Üçüncü modelde ise, dış hat kargo talebi ile gayrisafi yurtiçi hâsıla (GSYH), dış ticaret hacmi, sanayi üretim endeksi ve doğrudan yabancı yatırım tutarı arasındaki ilişki araştırılmıştır. Çalışmanın sonuçları, iç ve dış hat yolcu talebinde kişi başına gelir, gayrisafi yurtiçi hâsıla ve tüketici fiyat endeksi değişkenlerinin önemli ölçüde etkili olduğunu göstermektedir. Diş hat kargo talebinde ise, gayrisafi yurtiçi hâsıla ve sanayi üretim endeksi değişkenlerinin etkili olduğu gözlemlenmektedir.

Anahtar Kelimeler: Havayolu taşımacılı̆̆ , Makroekonomik değişkenler, VAR analizi

\section{Introduction}

Considering the historical development of air transport in Turkey, it has been in a process of rapid development and change particularly since 1983. To make the air transport market more liberal and to enable private enterprise to operate in this process, The Civil Aviation Law no. 2920 was enacted. After the enactment of this Law, the process of liberalization of air transport began in Turkey. As part of this process, a number of standards and regulations (SHY-6A and SHY-6B) have been introduced in order to enable the Turkish civil aviation sector to compete internationally and to carry out sector activities in a safe, reliable, quality and transparent manner. In this way, competition and security-based policies have been introduced in the air transportation service, the competition power has been increased and the economic and social development of the country has been accelerated.

\footnotetext{
* Dr. Öğr. Üyesi, İskenderun Teknik Üniversitesi, Havacılık Yönetimi, kasim.kiraci@iste.edu.tr

** Dr. Öğr. Üyesi, Anadolu Üniversitesi Havacilik ve Uzay Bilimleri Fakültesi, Havacilik Yönetimi Bölümü, $\underline{\text { ubattal@anadolu.edu.tr }}$
}

Kiracı, K. Battal, Ü., (2018). Macroeconomic Determinants of Air Transportation: A VAR Analysis on Turkey, Gaziantep University Journal of Social Sciences, 17(4), 1536-1557, Submission Date: 06-02-2018, Acceptance Date: 27-09-2018.

Araştırma Makalesi. 
With the liberal economic policies that began to be implemented in the 1980s, the "open system" airline industry has become considerably sensitive to the economic and political developments. This also paved the way for the air transport industry to both influence and be influenced by the macroeconomic indicators. In other words, the interaction between air transport and macroeconomic variables has greatly increased. Therefore, the empirical examination of the direction and severity of the relationship between air transport and macroeconomic variables has become important.

The related research literature indicates that one of the most important factors affecting air transport is household income, so there is a direct relationship between per capita income and air transport demand (Aderamo, 2010; Fernandes \& Pacheco, 2010; Baker, Merkert \& Kamruzzaman, 2015). In addition, findings indicating that macroeconomic factors such as consumer price index and interest rate are related to domestic and international air transport have also been reported (Abed, Ba-Fail, \& Jasimuddin, 2001; Ba-Fail, Abed, \& Jasimuddin, 2000; Aderamo, 2010; Erraitab, 2016; Erraitab, Hefnaoui, \& Mohammed, 2016). Accordingly, it is assumed that the increase in the consumer price index and interest rate variables, depending on both the decrease in the disposable income of the individual and the increase in the costs of the airline companies, is likely to affect the airline demand in the negative direction. Foreign trade volume, direct foreign investment and industrial production index macroeconomic variables are also assumed to be related to air cargo transport. In other words, there is strong evidence that there is a positive relationship between the mentioned macroeconomic variables and air cargo transport (Kasarda \& Green, 2005; Yao, 2005; Erraitab, Hefnaoui, \& Mohammed, 2016; Kiboi, Katuse, \& Mosoti, 2017). Therefore, understanding the multi-faceted relationship between air travel and cargo variables and macroeconomic factors is crucial to have a good grasp of the structure of the air transport industry.

This study of the relationship between macroeconomic factors and variables concerning air transport is divided into the following sections: In the following (second) section, the relevant literature is reviewed and the contribution made by the present study to the literature is demonstrated. In the third section, macroeconomic variables used in the study and their relation to air transport is explained. In the fourth section, the method and data set used in the study are presented. In the fifth section, the empirical results obtained from the analysis are shown in detail. In the final section, the results are discussed and suggestions for further studies are made.

\section{Related Literature}

In the literature, a number of studies have been conducted empirically on the relationship between air transport and macroeconomic variables. For example, Abed et al. (2001) examined the factors that determine international airline demand in Saudi Arabia, and Ba-Fail et al. (2000) empirically examined macroeconomic determinants of domestic airline demand. Valdes (2015) empirically studied the factors that determine the demand for air transport in middle income countries. Some recent empirical studies focused on the relationship between economic growth and domestic passenger demand in Brazil (Fernandes \& Pacheco, 2010); the dynamic relationship between airline demand and economic growth in the US (Chi \& Baek, 2013); the relationship between air transport and economic development in various regions of the US (Brueckner, 2003); the causality relationship between economic growth and air transport in South Asia (Hakim \& Merkert, 2016); the relationship between airline traffic and economic activities (Profillidis \& Botzoris, 2015); the relationship between domestic passenger traffic and economic growth in China (Hu et al., 2015); and the determinants of domestic air transport demand in Ethiopia (Sofany, 2016). In addition, Baker 
et al. (2015) examined the long-term causality relationship between regional air transport and economic growth in Australia.

Studies on the relationship between the variables of air transport and commercial activities have also been conducted. For example, Vijver et al. (2014) examined the relationship between trade volume and air travel in the Asia-Pacific region. Kulendran and Wilson (2000) analyzed the relationship between international trade and international air transport in the United States, Great Britain, New Zealand and Japan. It is also possible to find several studies in the literature where demand for air travel is measured or forecasts for airline demand are made. For example, Xiao et al. (2014) developed an adaptive-network-based fuzzy inference system methodology to forecast demand for air transport. Adrangi et al. (2001) used several monthly time series models to measure air transport demand in the United States. Bermúdez et al. (2007) made predictions about the future course of air transport in the UK based on the data from the 1949-2007 period. In addition, there are also studies examining the effects of events that occurred in the past on the development of air transport and the level of demand. One such study was carried out by Lai and Lu (2005). They conducted an empirical analysis of the September 11 terrorist attack in the US on the demand for air travel. In another study, Itoa and Lee (2005) examined the effect of the September 11 terrorist attack on demand using air transport data from 1986-2003.

In the literature, there are also studies analyzing the effect of air transport infrastructure investments on economic growth (Banister \& Berechman, 2001; Hensher, Truong, Mulley, \& Ellison, 2012), and a study examining the impact of domestic and international air transport on cities, taking macroeconomic factors such as population, tourism and employment into account (Full Hart \& O'Connor, 2013). In addition, some studies focus on the macroeconomic determinants of air cargo transport (Button \& Yuan, 2013; Kasarda \& Green, 2005).

The review of the relevant research literature in Turkey reveals that there are a few studies focusing on air transport. Using various scenarios, Ozan et al. (2014) tried to model the domestic air transport demand in Turkey by including variables such as income and jet fuel prices in their model. Sivrikaya and Bronze (2013) based their analysis on the total number of flights between two cities for the year 2011 in Turkey (origin and destinations) and studied the scope of this demand for domestic flights in Turkey. Doğan et al. (2006) examined the factors affecting the demand for transportation between cities. By conducting a questionnaire study on the students in Erzurum city, they analyzed the vehicle preference, the purpose of travel, the location and number of the travels, and some other factors with potential role in traveling. Our review did not yield any other studies that analyze the multidimensional relationship between macroeconomic factors and air transport in Turkey. Thus, it is expected that the present study will contribute to the literature and fill the gap in this field. In addition, determining the macroeconomic factors affecting air transport in Turkey can provide important information both for air transport policy makers and stakeholders regarding what is to be done for the improvement of air transport.

\section{Determinants of Air transport}

\section{Gross domestic product and per capita income}

Considering the factors that determine the air travel demand, per capita income is considered to be one of the important determinants. Valdes (2015) found that income in both middle-income and high-income countries significantly affected airline traffic. According to Valdes (2015), the most important factor affecting airline traffic, especially in the middle income countries, is income growth. Based on the previous studies in the literature, Baker et al. (2015) used the GDP (Per Capita Gross Domestic Product - \$) variable, which they 
assumed to be related to domestic passenger demand, and found that there is a long and short cycle of causality between regional aviation and economic growth.

\section{Interest rate}

The related research literature supports the view that there is an indirect relationship between interest rate and air transport. The increase in interest rates is perceived as a negative outlook for many countries. According to Kiboi et al. (2017, p.109), interest rates and ticket prices are largely related. Therefore, the increase in interest rates is expected to increase air ticket prices. As a result, the increase in ticket prices in air transport negatively affects the demand for air travel. Another dimension of the relationship between interest rates and air transport relates to the increase in interest rates and the postponement of non-compulsory expenditures by individuals. As the interest rate increases, the household saving rates increase, while the non-essential expenditures (especially holidays and travel) are reduced significantly. In this case, the demand for air transport is indirectly and adversely affected.

\section{Consumer price index}

Similar to the relationship between interest rate and air transport, the relationship between the consumer price index and air transport is thought to be indirect. Accordingly, the low consumer price index leads the household to save more and delay non-compulsory expenditures. In addition, the high inflation rate leads to a decrease in the disposable income of the individuals and reduces their purchasing power. Therefore, high inflation rate can affect the demand for air travel negatively. Many studies have examined the relationship between air transport and the consumer price index (Abed, Ba-Fail, \& Jasimuddin, 2001; Ba-Fail, Abed, \& Jasimuddin, 2000; Aderamo, 2010; Erraitab, 2016; Erraitab, Hefnaoui, \& Mohammed, 2016). The research in this area clearly verifies the strong negative relationship between consumer price index and air transport (Aderamo, 2010; Erraitab, 2016).

\section{Foreign trade volume}

It is emphasized in the research literature that there is a multifaceted and complex relationship between air transport and trade volume. Accordingly, although there is no direct relationship between the number of passengers carried by air and the volume of trade, there may be a strong relationship between air cargo transport and trade volume. In other words, it can be said that there is a strong causality relation between air cargo amount and trade volume (Kupfer, Meersman, Onghena, \& Voorde, 2009). In addition, research findings confirm that international travel increases in countries/regions where the volume of international trade is higher (Kulendran \& Wilson, 2000). The research studies in the literature clearly show a strong positive causality relationship between air cargo quantity and trade volume (Kasarda \& Green, 2005).

\section{Industrial production index}

In the literature, it is emphasized that the unit increase in industrial production, or the increase in industrial production volume increases the air cargo transportation. The academic studies on this issue underscore the close relation between freight transport and industrial production, and that these two variables affect each other considerably (Yao, 2005). There are also some reports indicating a partial relationship between global trade volume and air cargo transport. The IATA (2016) report points to a clear relationship between the rate of increase in air cargo transport and the rate of increase in industrial production.

\section{Direct foreign investment}

Some studies have been conducted on the relationship between direct foreign investment and air cargo transport. Since foreign direct investments are production-oriented 
investments, air cargo transportation can be used to export these investments. Therefore, a positive relationship is expected between air cargo transport and foreign direct investment. There are studies in the literature reporting that direct foreign investments affect air freight demand and are related to air freight transport (Erraitab, 2016, Kasarda \& Green, 2005, Valdes, 2015).

\section{Data Set, Models and Method}

The data set used in the study covers the period of 1983-2015. The main reason for the preference of 1983 as the start year is that the air transport activities were carried out only by the state before this date, and it was this year that the Civil Aviation Law no. 2920, allowing private enterprise to operate in aviation industry, went into effect.

The data used in the empirical analysis were obtained from the Eicon Datastream, World Bank, and Turkey Statistical Institute (TSI) databases. The macroeconomic variables assumed to affect domestic and international airline passenger demand and international airline cargo demand were used. Within the scope of the study, variables of GDP per capita, interest rate, and consumer price index were used as determinants of domestic airline demand. The variables used in the measurement of the international airline demand were determined as the GDP, the interest rate and the consumer price index. GDP, foreign trade volume, industrial production index, and foreign direct investment variables were used in determining the international cargo demand. The logarithm of all of the variables is taken. The letter "L" used at the beginning of the abbreviations stands for logarithm. Information on variables is shown in the Table below.

Table 1: Abbreviation and measurement indicator of variables

\begin{tabular}{lll}
\hline Variable & Abbreviation & Measurement Indicator \\
\hline Domestic Passenger & LDP & Number of Domestic Passengers (Person) \\
International Passenger & LIP & Number of International Passengers (Person) \\
International Cargo & LIC & Amount of International Cargo (Ton) \\
GDP per capita & LGDP & GDP per capita (\$) \\
Foreign Trade Volume & LFTV & Foreign Trade Volume (\$) \\
Gross Domestic Product & LGDP & Gross Domestic Product (2010 Prices \$) \\
Direct Foreign Investment & LDFI & Direct Foreign Investment $(\$)$ \\
Interest Rate & LIR & Interest rate \\
Industrial Production Index & LIPI & Industrial Production Index \\
Consumer Price Index & LCPI & Consumer price index \\
\hline
\end{tabular}

Based on the studies in the literature, three basic variables were used in the study to measure air transport demand. These were determined as the number of domestic passengers, the number of international passengers, and the amount of international cargo. In addition, the macroeconomic variables assumed to be associated with each of the three basic variants mentioned were identified. Below are the models of the key indicators of air transport.

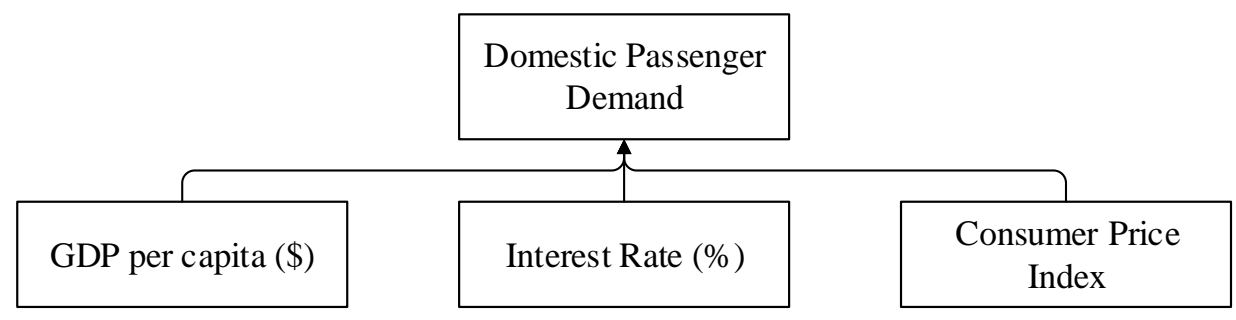


Figure 1: Model 1 (Domestic passenger demand determinants)

Model 1 includes default macroeconomic variables that affect domestic passenger demand in Turkey. Three different variables are used in this context. These are Per Capita Gross Domestic Product (\$), Interest rate (\%) and Consumer Price Index (CPI).

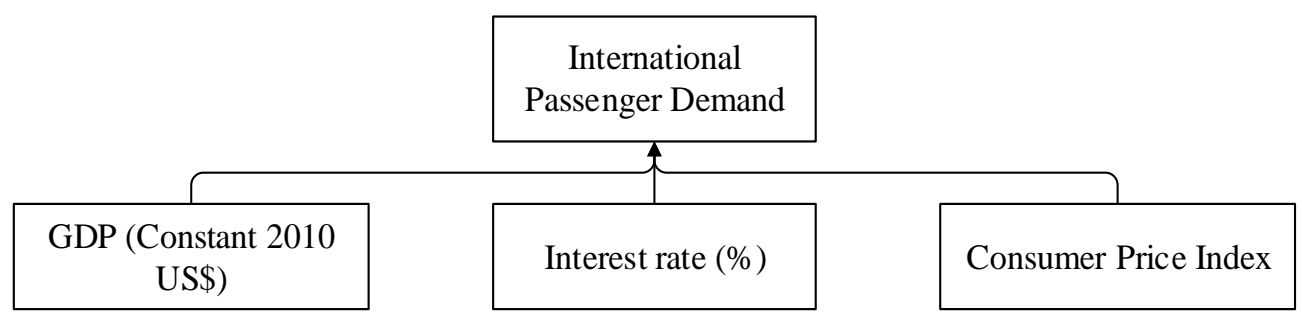

Figure 2: Model 2 (International passenger demand determinants)

Model 2 shows the model used for international passenger demand in Turkey. Just as in the measurement of the domestic passenger demand, three different macroeconomic variables are used here. The variables used in measuring international passenger demand were determined as gross domestic product ( $\$$ for 2010 prices), Interest rate and Consumer Price Index (CPI).

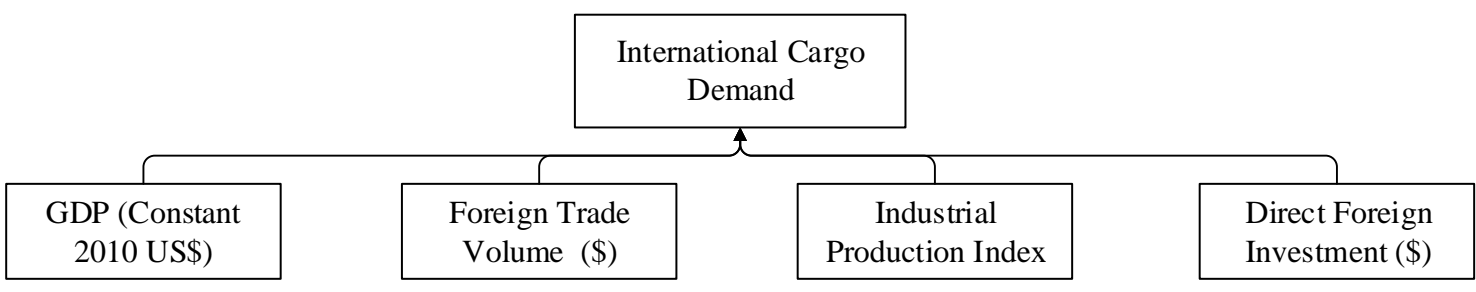

Figure 3: Model 3 (International cargo demand determinants)

Model 3 includes the default macroeconomic variables that affect international cargo demand in Turkey. Three different macroeconomic variables were used to determine the international cargo demand. These variables are Gross Domestic Product (\$ at 2010 Prices), Foreign Trade Volume (\$), Industrial Production Index, and Foreign Direct Investment (\$).

In the study, the stability of the series was examined using the Augmented Dickey Fuller (ADF), Philips-Peron (PP) unit root tests. After the variables were stabilized, the optimal delay lengths were determined. The subsequent sections present the results of the Impulse-Response analysis, the variance decomposition analysis, and the Granger causality analysis.

In this section, to clarify the effect of the macro-economic variables on Turkish air transport, three VAR (vector autoregressive model) models are proposed. The interpretation of the VAR model proposed by Sims (1980) for the first time as a time series prediction model is called the standard or conventional VAR model. Structural interpretation of the VAR model is called "Structural VAR". A standard VAR model for two variables can be shown as follows (Tari, 2012, pp. 452):

$$
Y_{t}=\alpha_{10}+\sum_{i=1}^{p} \alpha_{11 i} Y_{t-i}+\sum_{i=1}^{p} \alpha_{12 i} Y_{t-i}+\varepsilon_{1 t}
$$




$$
X_{t}=\alpha_{20}+\sum_{i=1}^{p} \alpha_{21 i} Y_{t-i}+\sum_{i=1}^{p} \alpha_{22 i} Y_{t-i}+\varepsilon_{2 t}
$$

Here, $\alpha_{i 0}$ is the constant term, $\alpha_{i j k}$ is the parameter for delaying the jth variable in the equation, $\varepsilon_{i t}$ is the error term, and $p$ is the number of delays (Y1lmaz \& Kaya, 2007, p. 95).

In the analysis using the VAR model, it is not possible to directly interpret the parameters economically. For this reason, VAR models are generally used for impulseresponse functions, variance decomposition analyzes and Granger causality analyzes to obtain meaningful results. Impulse-Response functions, variance decomposition, and Granger causality analysis will be shown below.

\section{Empirical findings}

\section{Unit root analysis results}

Before the analysis begins, it is necessary to examine whether the series have unit roots and to determine the degree of integration. In the literature, ADF and PP unit root tests are the most-commonly used tests for stability analysis of the series. The test results are presented in the following Tables.

Table 2: Augmented dickey-fuller (ADF) unit root test results

\begin{tabular}{lcrrr}
\hline & \multicolumn{2}{c}{ ADF- Test Statistics (Level) } & \multicolumn{2}{c}{ ADF- Test Statistics (1st Difference) } \\
\cline { 2 - 5 } Constant & Constant and Trend & \multicolumn{1}{c}{ Constant } & Constant and Trend \\
\hline LDP & $0.137(1)[0.9636]$ & $-2.411(1)[0.3671]$ & $-3.887(0)[0.0057]$ & $-3.931(0)[0.0226]$ \\
LIP & $-1.690(0)[0.4264]$ & $-2.402(0)[0.3715]$ & $-6.229(0)[0.0000]$ & $-6.456(0)[0.0000]$ \\
LIC & $-2.038(0)[0.2697]$ & $-2.801(0)[0.2072]$ & $-6.743(0)[0.0000]$ & $-5.481(1)[0.0006]$ \\
LGDP & $-1.127(0)[0.6928]$ & $-2.390(0)[0.3773]$ & $-6.091(0)[0.0000]$ & $-6.106(0)[0.0001]$ \\
LFTV & $-0.976(0)[0.7496]$ & $-2.233(0)[0.4560]$ & $-5.856(0)[0.0000]$ & $-5.802(0)[0.0002]$ \\
LGDP & $-0.052(0)[0.9566]$ & $-2.333(0)[0.4053]$ & $-5.847(0)[0.0000]$ & $-5.786(0)[0.0002]$ \\
LDFI & $-0.552(0)[0.4946]$ & $-2.706(0)[0.2407]$ & $-5.861(0)[0.0000]$ & $-5.761(0)[0.0003]$ \\
LIR & $-0.398(0)[0.8979]$ & $-1.716(0)[0.7208]$ & $-6.223(0)[0.0000]$ & $-6.329(0)[0.0001]$ \\
LIPI & $-0.497(0)[0.8791]$ & $-3.294(0)[0.0854]$ & $-6.115(0)[0.0000]$ & $-6.024(0)[0.0001]$ \\
LCPI & $-0.371(0)[0.9025]$ & $-2.091(0)[0.5306]$ & $-5.337(0)[0.0001]$ & $-5.332(0)[0.0008]$ \\
\hline
\end{tabular}

Note: The values in parentheses indicate the selected delay lengths according to the SIC (Schwarz Info Criteria) and the values in square brackets indicate the probability values of the ADF statistic.

The findings of the Augmented Dickey-Fuller (ADF) unit root test are presented in the Table above. According to this, all variables have unit root in level. In other words, the $\mathrm{H}_{0}$ hypothesis, established as "unit root" in the level values of the variables, was not rejected, and thus was accepted. In this case, the first difference of the series should be taken and the unit root entity should be tested. When the first differences of the series are taken, it is seen that all of them become stationary, in other words, the hypothesis $\mathrm{H}_{0}$ which is formed as "unit root" is rejected.

Table 3: Philips-Peron (PP) unit root test results

\begin{tabular}{lcrcr}
\hline & \multicolumn{2}{c}{ PP- Test Statistics (Level) } & \multicolumn{2}{c}{ PP- Test Statistics (1st Difference) } \\
\cline { 2 - 5 } & \multicolumn{1}{c}{ Constant } & Constant and Trend & \multicolumn{1}{c}{ Constant } & Constant and Trend \\
\hline LDP & $0.339(2)[0.9768]$ & $-1.571(0)[0.7819]$ & $-3.854(3)[0.0062]$ & $-3.790(4)[0.0307]$ \\
LIP & $-2.251(6)[0.1933]$ & $-2.285(3)[0.4294]$ & $-6.239(1)[0.0000]$ & $-6.741(4)[0.0000]$ \\
LIC & $-3.573(10)[0.0122]$ & $-2.756(3)[0.2227]$ & $-6.919(2)[0.0000]$ & $-8.892(9)[0.0000]$ \\
LGDP & $-1.127(0)[0.6928]$ & $-2.441(1)[0.3527]$ & $-6.090(0)[0.0000]$ & $-6.108(1)[0.0001]$ \\
LFTV & $-0.988(1)[0.7454]$ & $-2.315(2)[0.4141]$ & $-5.857(1)[0.0000]$ & $-5.802(1)[0.0002]$ \\
LGDP & $-0.121(3)[0.9625]$ & $-2.333(0)[0.4053]$ & $-5.983(4)[0.0000]$ & $-5.948(4)[0.0002]$ \\
LDFI & $-1.574(7)[0.4837]$ & $-2.821(2)[0.2008]$ & $-6.163(6)[0.0000]$ & $-6.111(7)[0.0001]$
\end{tabular}




\begin{tabular}{lrrrr}
\hline \hline LIR & $-0.298(1)[0.9144]$ & $-1.715(0)[0.7208]$ & $-6.202(2)[0.0000]$ & $-6.328(0)[0.0001]$ \\
LIPI & $-0.411(14)[0.8956]$ & $-3.028(5)[0.1404]$ & $-8.594(12)[0.0000]$ & $-9.465(13)[0.0000]$ \\
LCPI & $-0.371(0)[0.9025]$ & $-2.118(2)[0.5167]$ & $-5.337(1)[0.0001]$ & $-5.337(2)[0.0007]$ \\
\hline
\end{tabular}

Note: The values in parentheses indicate the number of delays for Bartlett Kernel in the direction of the Newey West proposal, and the values in square brackets indicate the probability values of the PP statistic.

The findings of the Philips-Peron (PP) unit root test are presented in the Table above. Obtained findings are consistent with ADF unit root test. In the Philips-Peron (PP) unit root test, it is clear that the series have unit root in the level but become stationary when the first difference is taken. Therefore, the series will be analyzed with the first difference values.

\section{Pretest results}

In order to perform the Vector Autoregressive Model (VAR) analysis, it is necessary to determine the most appropriate lag length. Autocorrelation and heteroscedasticity pre-tests should be performed on the determined VAR model after determining the appropriate lag length. Preliminary results are presented below for Model 1, Model 2 and Model 3. In the VAR model, optimal lag length is determined by considering one or more of the information criteria. This study is based on the lag length of the model in which the model does not contain autocorrelation, heteroscedasticity problems, and all the inverse roots are included in the unit circle.

Table 4: Autocorrelation LM Test results for model 1

\begin{tabular}{ccc}
\hline Lag length & LM-Stat & Prob. \\
\hline $\mathbf{1}$ & 12.22857 & 0.7281 \\
$\mathbf{2}$ & 16.38402 & 0.4265 \\
$\mathbf{3}$ & 13.14885 & 0.6618 \\
$\mathbf{4}$ & 18.66636 & 0.2863 \\
\hline
\end{tabular}

Note: Hypothesis tests were based on a significance level of $0.01(1 \%), 0.05(5 \%)$ and $0.1(10 \%)$.

Table 4 shows the autocorrelation test results for the VAR (2) model. As can be seen from the Table, the hypothesis $\mathrm{H}_{0}$ established as "no autocorrelation" is accepted until 4th delay (the value of "Prob" in the Table is larger than 0.05, indicating that the hypothesis $\mathrm{H}_{0}$ is accepted).

Table 5: White heteroscedasticity test results for model 1

\begin{tabular}{ccc}
\hline Chi-Square Value & Degree of Freedom & Prob. \\
\hline 176.0191 & 160 & 0.1829 \\
\hline Note: Hypothesis tests were based on a significance level of $0.01(1 \%), 0.05(5 \%)$ and $0.1(10 \%)$. &
\end{tabular}

Table 5 presents the heteroscedasticity analysis results for Model 1. According to this, the hypothesis $H_{0}$ formed as "there is no heteroscedasticity" is accepted, and therefore there is no problem of heteroscedasticity. 
Inverse Roots of AR Characteristic Polynomial

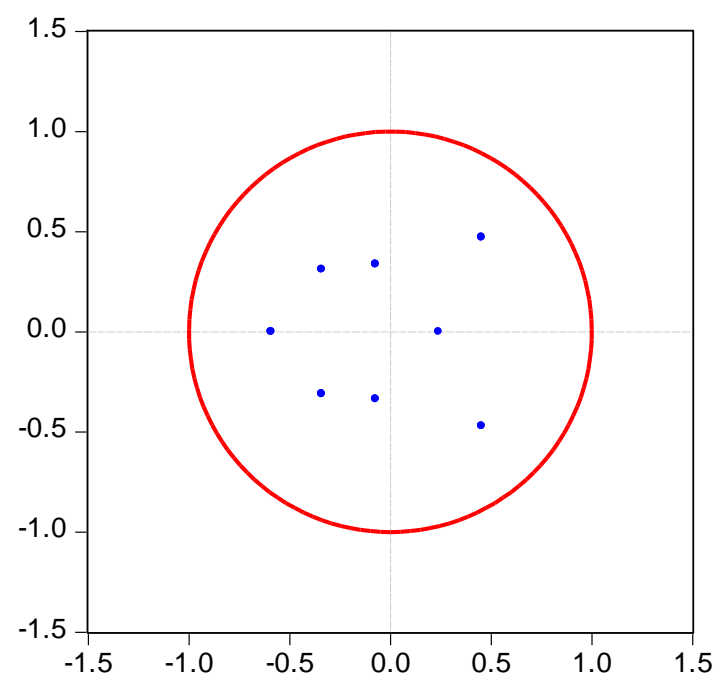

Figure 4: VAR Stability test results for model 1

In Figure 4, the position of the opposite roots of the AR characteristic polynomial in the unit circle is given. All of the roots need to be placed in the unit circle. It is obvious from the Figure that the created model is stable, with no instability problems.

Table 6: Autocorrelation LM Test Results for Model 2

\begin{tabular}{ccc}
\hline Lag length & LM-Stat & Prob \\
\hline $\mathbf{1}$ & 8.022198 & 0.9482 \\
$\mathbf{2}$ & 9.680258 & 0.8828 \\
$\mathbf{3}$ & 13.82344 & 0.6119 \\
$\mathbf{4}$ & 12.69002 & 0.6953 \\
\hline
\end{tabular}

Note: Hypothesis tests were based on a significance level of $0.01(1 \%), 0.05(5 \%)$ and $0.1(10 \%)$.

Table 6 shows the autocorrelation test results for the VAR (1) model. As can be seen from the Table, until the fourth delay, the hypothesis $H_{0}$ formed as "no autocorrelation" is accepted. Therefore, the autocorrelation problem does not exist in the generated model.

Table 7: White heteroscedasticity test results for model 2

\begin{tabular}{lll}
\hline Chi-Square Value & Degree of Freedom & Prob. \\
\hline 83.44343 & 80 & 0.3741 \\
\hline Note: Hypothesis tests were based on a significance level of $0.01(1 \%), 0.05(5 \%)$ and $0.1(10 \%)$.
\end{tabular}

Table 7 presents the heteroscedasticity analysis results for Model 2. According to this, the hypothesis $\mathrm{H}_{0}$ formed as "no heteroscedasticity" is accepted, so there is no problem of heteroscedasticity. 
Inverse Roots of AR Characteristic Polynomial

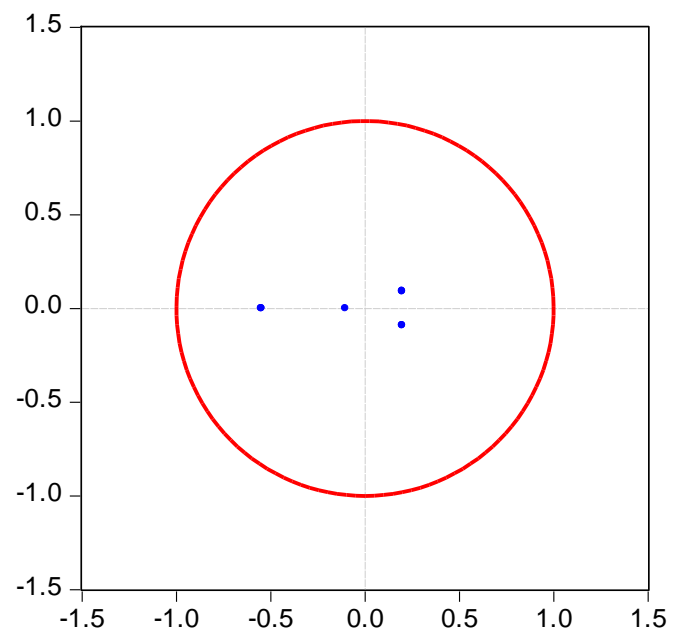

Figure 5: VAR Stability test results for model 2

In Figure 5, the position of the opposite roots of the AR characteristic polynomial in the unit circle is given. The positioning of the entire roots within the unit circle is important for the significance of the model. As can be seen, the model has no problems in terms of stability.

Table 8: Autocorrelation LM test results for model 3

\begin{tabular}{ccc}
\hline Lag length & LM-Stat & Prob \\
\hline $\mathbf{1}$ & 26.06273 & 0.4043 \\
$\mathbf{2}$ & 20.1872 & 0.7369 \\
$\mathbf{3}$ & 28.68333 & 0.2774 \\
$\mathbf{4}$ & 31.79712 & 0.1640 \\
\hline
\end{tabular}

Note: Hypothesis tests were based on a significance level of $0.01(1 \%), 0.05(5 \%)$ and $0.1(10 \%)$.

Table 8 shows the autocorrelation test results for the VAR (2) model. As shown in the Table, the hypothesis $\mathrm{H}_{0}$, formed as "no autocorrelation" until four delays, is accepted. The autocorrelation problem in the selected VAR model is thus resolved.

Table 9: White heteroscedasticity test results for model 3

\begin{tabular}{ccc}
\hline Chi-Square Value & Degree of Freedom & Prob \\
\hline 301.67 & 300 & 0.4621 \\
\hline
\end{tabular}

Note: Hypothesis tests were based on a significance level of $0.01(1 \%), 0.05(5 \%)$ and $0.1(10 \%)$.

Table 9 shows the heteroscedasticity analysis results for Model 3. Accordingly, the hypothesis $\mathrm{H}_{0}$ established as "there is no heteroscedasticity" is accepted, so the heteroscedasticity problem ceases to exist. 
Inverse Roots of AR Characteristic Polynomial

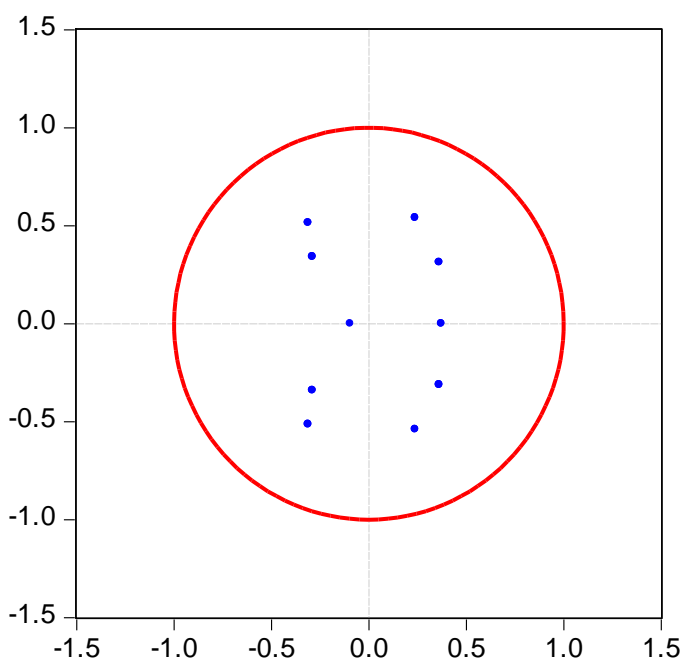

Figure 6: VAR stability test results for model 3

Figure 6 shows the position of the inverted roots of the AR characteristic polynomial in the unit circle. All of the roots need to be placed in the unit circle. When the Figure is examined, it is obvious that the created model does not have any problems in terms of stability.

Impulse-Response, variance decomposition, and Granger causality analyzes can be performed after determining the VAR models to solve unit root, autocorrelation, and heteroscedasticity problems for all three models (Model 1, Model 2 and Model 3). These analysis results will be presented in the section below.

\section{Impulse-Response Functions}

In the Impulse-Response analyses, the responses of other variables to a unit of standard deviation shock occurring in one variable are shown in a graph. The ImpulseResponse analysis is used to see the reactions that take place in the resultant shocks and examine the duration of their adaptation. In the next section, Model 1, Model 2, and Model 3 Impulse-Response analysis results are shown. 
Response to Cholesky One S.D. Innovations \pm 2 S.E.

Response of International Passenger to GDP per capita

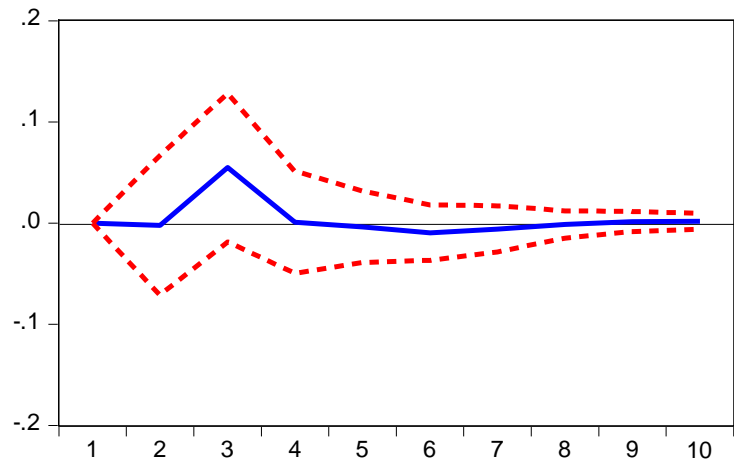

Response of Domestic Passenger to Interest Rate

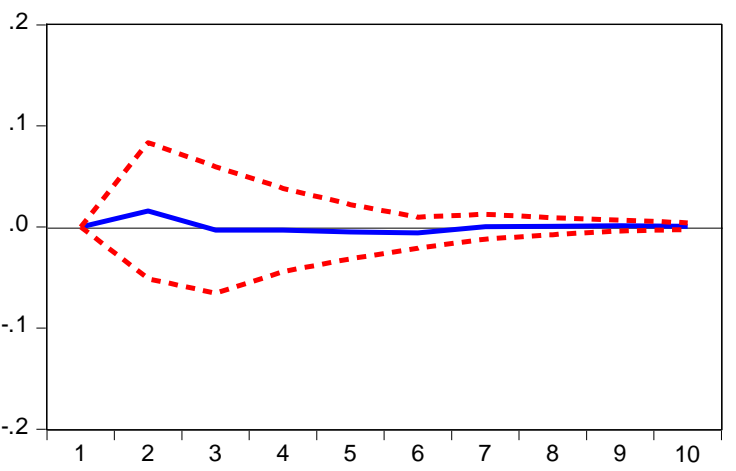

Response of Domestic Passenger to CPI

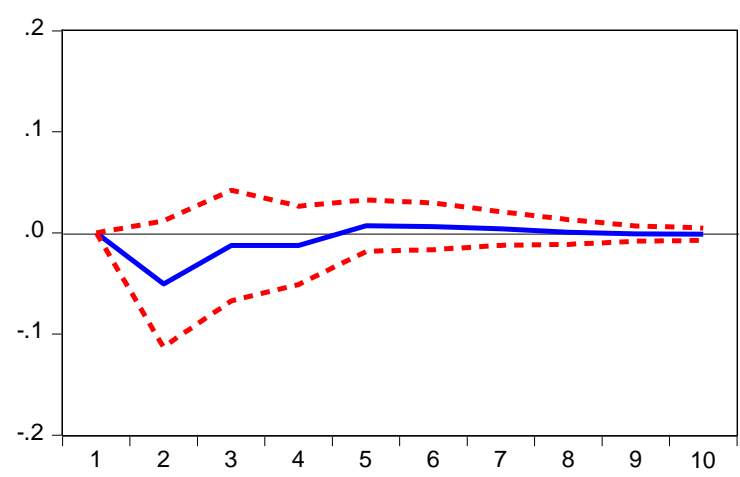

Response of GDP per capita to Domestic Passenger

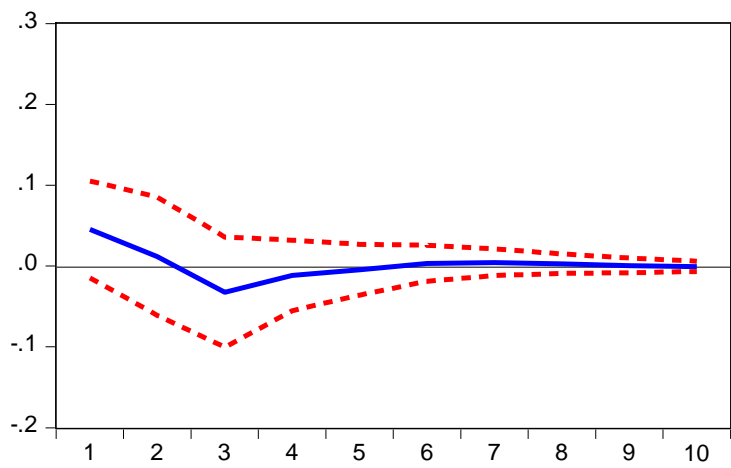

Response of Interest Rate to Domestic Passenger

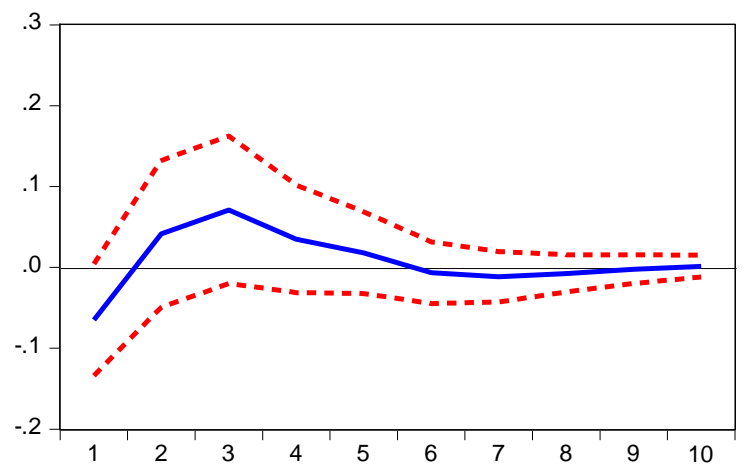

Response of CPI to Domestic Passenger

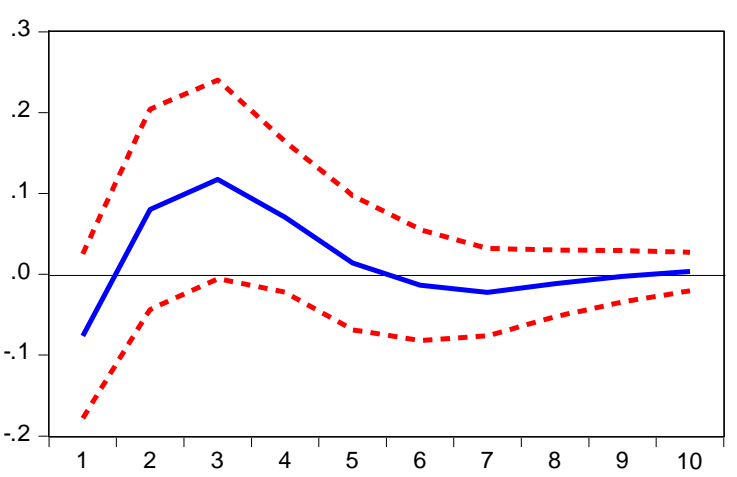

Figure 7: Impulse-Response analysis graphs for model 1

Figure 7 shows Impulse-Response analysis results are displayed between variables for Model 1. Accordingly, as a result of a shock to the per capita income, the number of domestic passengers rises from the second period onward, and this increase continues until the fourth period. Due to a shock in the number of domestic passengers, the GDP per capita is affected positively in the first two periods and then returns to normal by being affected negatively in the subsequent periods. It seems that the shock in the interest rates does not cause a significant change in the number of domestic passengers. On the other hand, the interest rate seems to be negatively affected by a shock in the number of domestic passengers in the first period, and then turning positive and normalizing in the following periods. As a result of a shock in the consumer price index, the number of domestic passengers is affected negatively from the first period on, and this effect continues until the end of the fourth period. The number of domestic 
passengers also shows that the consumer price index variable responds similarly to the interest rate variable in the resulting shock.

Response to Cholesky One S.D. Innovations \pm 2 S.E.

Response of International Passenger to GDP

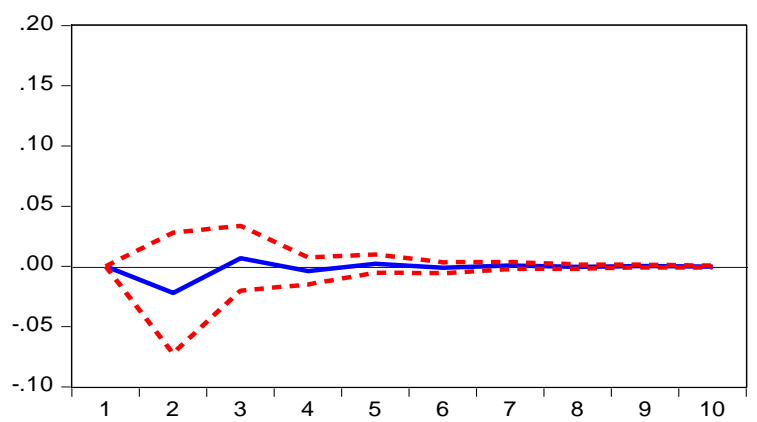

Response of International Passenger to Interest Rate

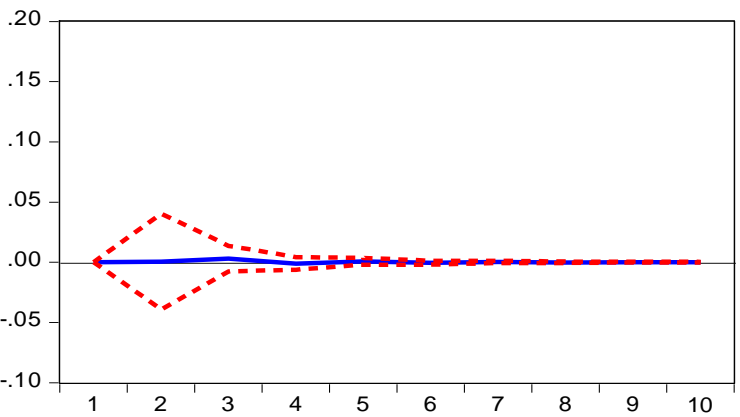

Response of International Passenger to CPI

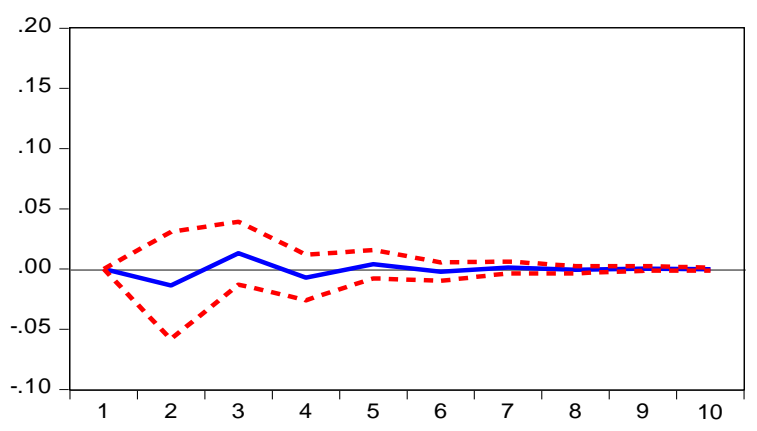

Response of GDP to International Passenger

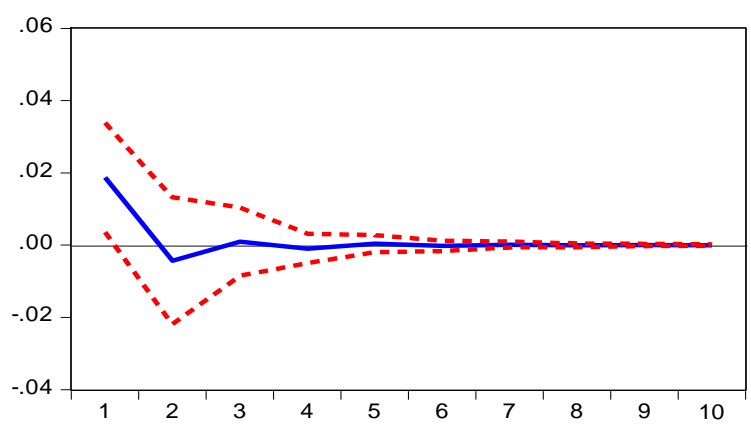

Response of Interest Rate to International Passenger

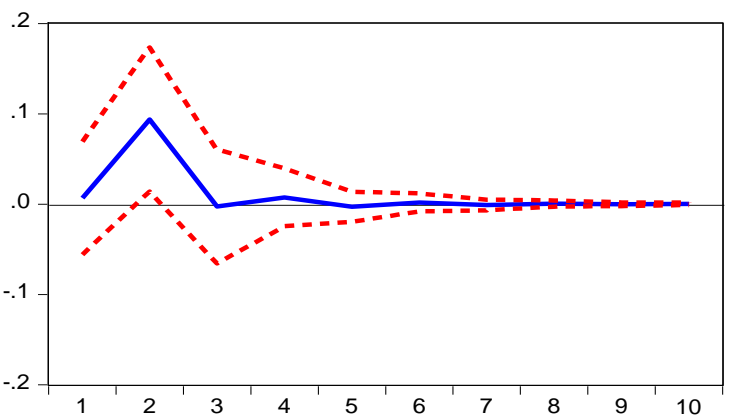

Response of CPI to International Passenger

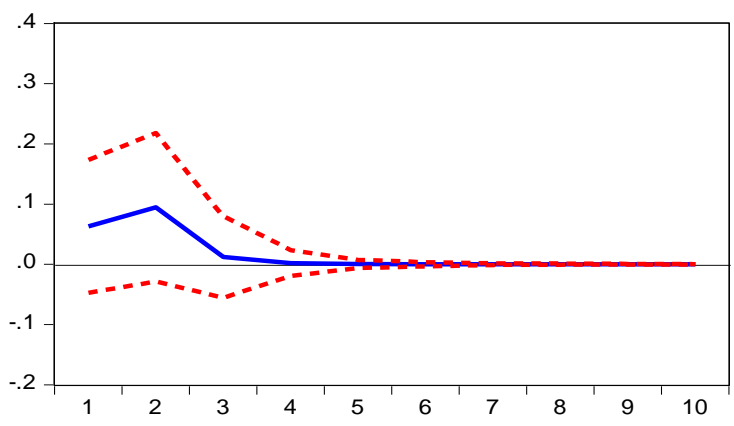

Figure 8: Impulse-Response analysis graphs for model 2

Figure 8 shows the Impulse-Response analysis results between variables for Model 2. As a result of a shock in the GDP, it seems that the number of international passengers experiences a brief cyclical decline and that the effect is lost in the short run. The number of international passengers also appears to be affected positively by the GDP in a shocking event, and this effect appears to normalize after a period of time. It seems that a shock to interest rates does not cause a significant change in the number of international passengers. On the other hand, the number of international passengers also shows that the interest rate increases from the first period on and this effect is normalized in the third period. As a result of a shock in the consumer price index, the number of international passengers declines until the second period, after which the effect disappears. The number of international passengers also shows that the consumer price index rises as a result of the shock to the market, and that this effect is not present at the end of the third period. 
Response to Cholesky One S.D. Innovations \pm 2 S.E.

Response of International Cargo to GDP

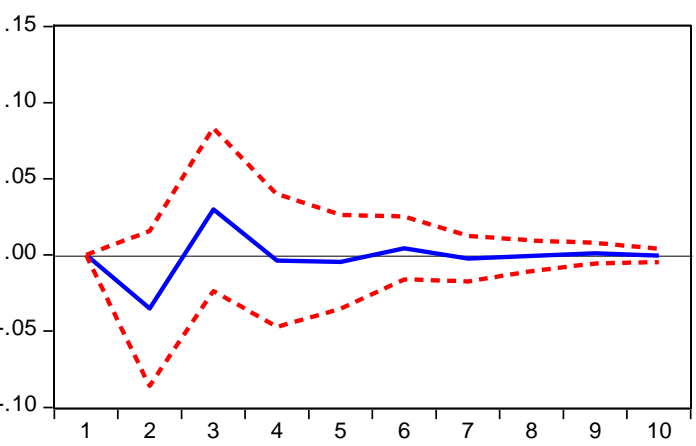

Response of International Cargo to IPI

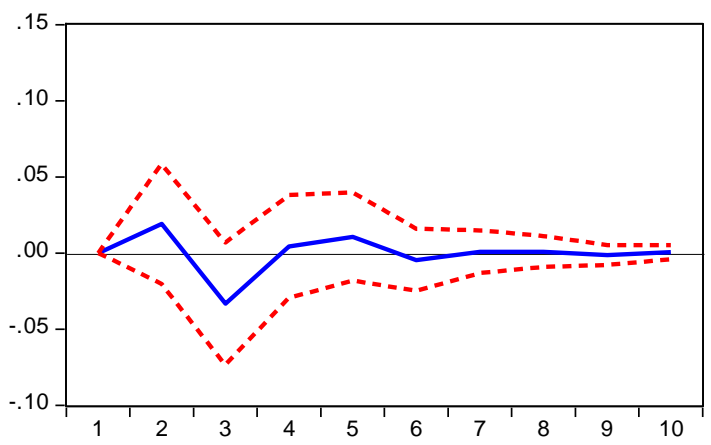

Response of International Cargo to FTV

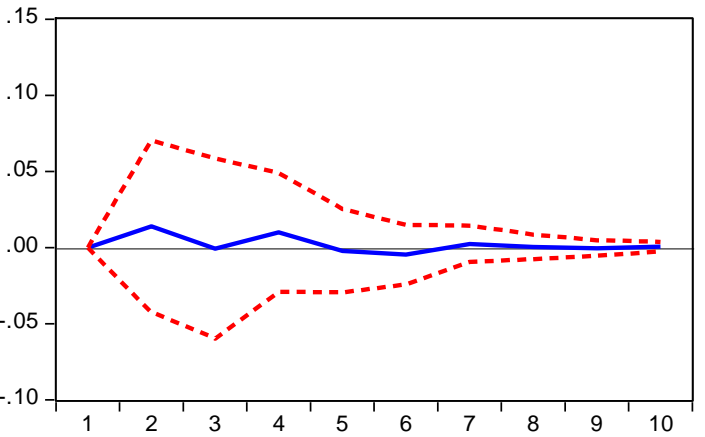

Response of International Cargo to DFI

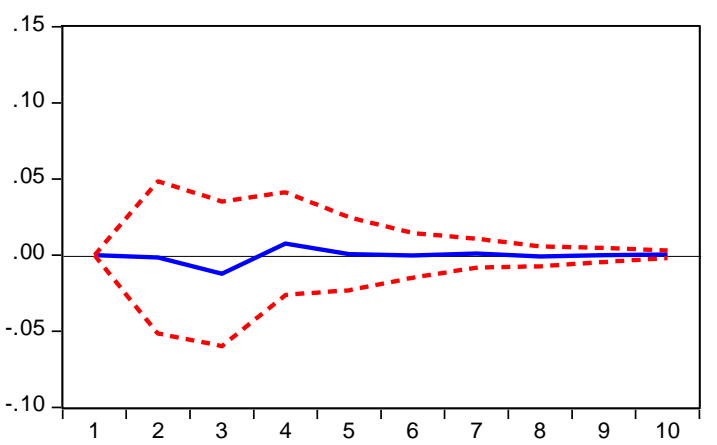

Response of GDP to International Cargo

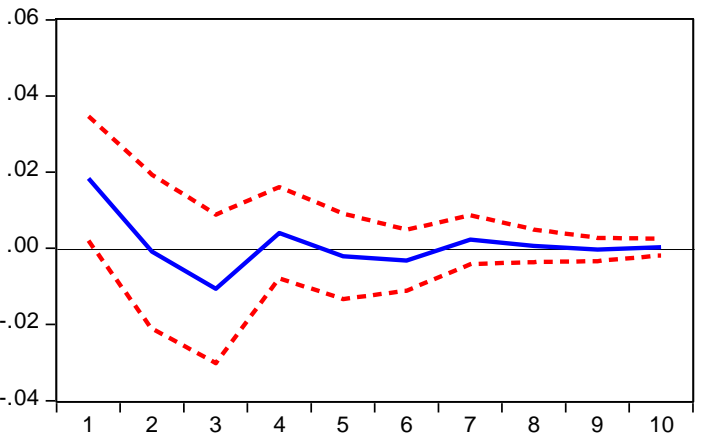

Response of IPI to International Cargo

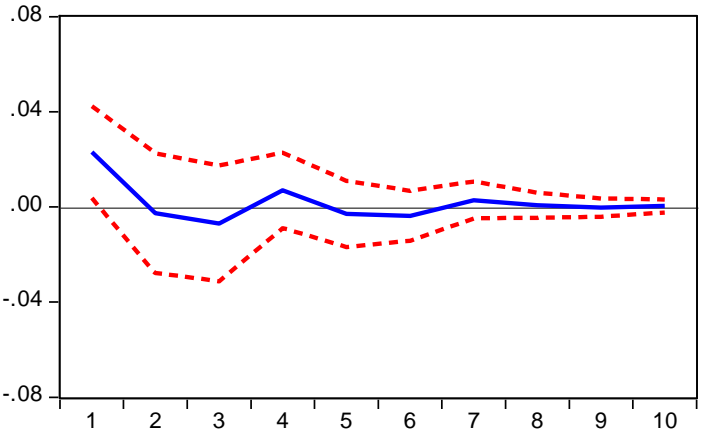

Response of FTV to DIS HAT KARGO

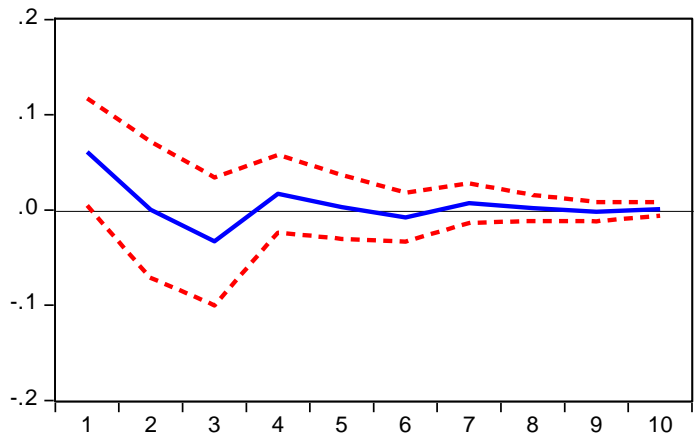

Response of DFI to International Cargo

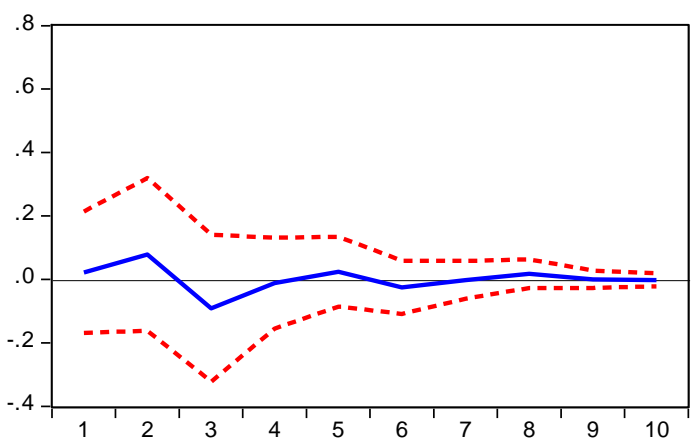

Figure 9: Impulse-Response analysis graphs for model 3

Figure 9 shows the Impulse-Response analysis results for variables for Model 3. According to this figure, the negative effect of a shock in the GDP on the international cargo amount lasts until the end of the second period and then disappears and returns to the positive. As a result of a shock in international cargo amount, the GDP is positive in the first period, 
turns to negative in the second period, and disappears at the end of the third period. A shock in the industrial production index appears to affect the international cargo quantity as positive in the second period and negatively in the third period. A shock in the quantity of international cargo has a positive effect on the industrial production index, progressing towards negativity. In addition, because of a shock in the volume of foreign trade, the amount of international cargo is positively affected, albeit at a low level. The effect of a shock in the amount of international cargo on foreign trade volume is similar to its effect on the industrial production index. After a shock in foreign direct investment, no significant change can be observed in the amount of international cargo. As a result of a shock in the amount of international cargo, foreign direct investments are affected positively in the first period and negatively in the latter period.

\section{Variance Decomposition Analysis}

After performing impulse-response analyses in VAR models, variance decomposition analysis is conducted. In this analysis, the source and rate of change are expressed both in themselves and in other variables. In other words, the analysis of the effect of the source of change for each variable over time is performed through this analysis. In the following section, variance decomposition analysis results for Model 1, Model 2 and Model 3 are presented.

Table 10: Domestic passenger variance decomposition

\begin{tabular}{cccccc}
\hline Period & Standard Error & LDP & LGDP & LIR & LCPI \\
\hline $\mathbf{1}$ & 0.156322 & 100.0000 & 0.000000 & 0.000000 & 0.000000 \\
$\mathbf{2}$ & 0.174968 & 90.81344 & 0.016140 & 0.831074 & 8.339351 \\
$\mathbf{3}$ & 0.183983 & 82.31471 & 8.899824 & 0.780559 & 8.004906 \\
$\mathbf{4}$ & 0.185126 & 82.04891 & 8.791513 & 0.798822 & 8.360756 \\
$\mathbf{5}$ & 0.187294 & 82.20417 & 8.633585 & 0.846523 & 8.315723 \\
$\mathbf{6}$ & 0.188194 & 81.90848 & 8.812836 & 0.931874 & 8.346809 \\
$\mathbf{7}$ & 0.188342 & 81.78871 & 8.898479 & 0.930556 & 8.382254 \\
$\mathbf{8}$ & 0.188396 & 81.79048 & 8.899413 & 0.931153 & 8.378957 \\
$\mathbf{9}$ & 0.188465 & 81.79123 & 8.898611 & 0.935249 & 8.374914 \\
$\mathbf{1 0}$ & 0.188492 & 81.78290 & 8.903154 & 0.936117 & 8.377830 \\
\hline
\end{tabular}

Table 3.13 shows the results of the analysis of variance decomposition related to the number of domestic passengers (LDP) variable. Accordingly, the change in the domestic passenger variable is determined by itself at the beginning of the period. Consumer price index (LCPI) in the second period, and per capita income (LGDP) in the third period seem to be effective. The effect of per capita income on the change in the domestic passenger variable seems to have increased throughout the years. At the end of the tenth period, approximately $9 \%$ of the change in the domestic passenger variable is determined by the per capita income (LGDP) and 8,3\% by the consumer price index (LCPI). It is observed that the interest rate variable has no effect on the change in the domestic passenger variable.

Table 11: International passenger variance decomposition

\begin{tabular}{cccccc}
\hline Period & Standard Error & LIP & LGDP & LIR & LCPI \\
\hline $\mathbf{1}$ & 0.133097 & 100.0000 & 0.000000 & 0.000000 & 0.000000 \\
$\mathbf{2}$ & 0.136457 & 96.35214 & 2.628092 & 0.001786 & 1.017978 \\
$\mathbf{3}$ & 0.137402 & 95.21261 & 2.829037 & 0.049277 & 1.909074 \\
$\mathbf{4}$ & 0.137661 & 94.86930 & 2.899931 & 0.055261 & 2.175511
\end{tabular}




\begin{tabular}{cccccc}
$\mathbf{5}$ & 0.137743 & 94.76267 & 2.922700 & 0.058045 & 2.256582 \\
$\mathbf{6}$ & 0.137767 & 94.73075 & 2.928963 & 0.058797 & 2.281492 \\
$\mathbf{7}$ & 0.137775 & 94.72108 & 2.930957 & 0.059029 & 2.288938 \\
$\mathbf{8}$ & 0.137777 & 94.71816 & 2.931545 & 0.059100 & 2.291199 \\
$\mathbf{9}$ & 0.137778 & 94.71727 & 2.931724 & 0.059121 & 2.291881 \\
$\mathbf{1 0}$ & 0.137778 & 94.71701 & 2.931778 & 0.059127 & 2.292087 \\
\hline
\end{tabular}

Table 3.14 presents the variance decomposition analysis results for the number of international passengers (LIP) variable. According to this table, $96.35 \%$ of the variation in the number of international passengers in the second period is explained by itself, $2.62 \%$ by GDP (LGDP), and $1.01 \%$ by consumer price index (LCPI). Analysis results show that the weight of LGSHH and LTFFE variables increases over the years regarding the change in the number of international passengers. According to this, at the end of the tenth period, approximately $3 \%$ of the change in the international passenger variable is determined by LGDP, and $2.3 \%$ by the consumer price index (LCPI).

Table 12: International cargo variance decomposition

\begin{tabular}{ccccccc}
\hline Period & Standard Error & LIC & LGDP & LFTV & LIPI & LDFI \\
\hline $\mathbf{1}$ & 0.117499 & 100.0000 & 0.000000 & 0.000000 & 0.000000 & 0.000000 \\
$\mathbf{2}$ & 0.125166 & 88.57260 & 7.86125 & 1.230989 & 2.316517 & 0.018646 \\
$\mathbf{3}$ & 0.135433 & 78.50014 & 11.56729 & 1.054578 & 8.018913 & 0.859081 \\
$\mathbf{4}$ & 0.137072 & 78.03261 & 11.36578 & 1.546951 & 7.921976 & 1.132686 \\
$\mathbf{5}$ & 0.137892 & 77.55823 & 11.34410 & 1.555640 & 8.420557 & 1.121469 \\
$\mathbf{6}$ & 0.138161 & 77.30545 & 11.40530 & 1.669757 & 8.501505 & 1.117998 \\
$\mathbf{7}$ & 0.138346 & 77.29748 & 11.40588 & 1.694292 & 8.481508 & 1.120843 \\
$\mathbf{8}$ & 0.138364 & 77.29176 & 11.40524 & 1.694353 & 8.482651 & 1.126002 \\
$\mathbf{9}$ & 0.138379 & 77.27891 & 11.40918 & 1.694997 & 8.491043 & 1.125874 \\
$\mathbf{1 0}$ & 0.138385 & 77.27669 & 11.40908 & 1.695979 & 8.491624 & 1.126623 \\
\hline
\end{tabular}

Table 3.15 shows the variance decomposition analysis results for the international cargo variable (LIC). Accordingly, the change in the international cargo variable is selfdetermined at the beginning of the period. From the third period, the changes in the international cargo variable seem to be influenced by the gross domestic product (LGDP) and industrial production index (LIPI) variables. In the third period, $78.5 \%$ of the change in the international cargo variable is explained by itself, $11.5 \%$ by gross domestic product (LGDP) and $8 \%$ by industrial production index (LIPI). In addition, the effect of other variables on the changes in the international cargo variable does not appear to vary significantly over the years. At the end of the tenth period, the change in the international cargo variable is determined by the variables of foreign trade volume (LFTV) and foreign direct investment (LDFI), with $1.69 \%$, and $1.12 \%$, respectively.

\section{Granger Causality Test Results}

The Granger causality test is used primarily to determine whether there is an association between two variables and to analyze whether the relationship is unidirectional or bidirectional. The results of the Granger causality analysis for Model 1, Model 2 and Model 3 are presented below.

Table 13: Granger Causality/Block exogeneity wald test for model 1

\begin{tabular}{|l|l|l|}
\hline Sample: 19832015 & & \\
\hline Number of Observations: 31 & \\
\hline
\end{tabular}




\begin{tabular}{|c|c|c|c|}
\hline \multicolumn{3}{|c|}{ Dependent Variable: LDP } & \multirow[b]{2}{*}{ Prob. } \\
\hline Excluded & Chi-Square Value & Degree of Freedom & \\
\hline LGDP & 0.169679 & 2 & 0.9187 \\
\hline LIR & 2.269471 & 2 & 0.3215 \\
\hline LCPI & 2.76465 & 2 & 0.2510 \\
\hline All & 6.885918 & 6 & 0.3315 \\
\hline \multicolumn{3}{|c|}{ Dependent Variable: LGDP } & \\
\hline Excluded & Chi-Square Value & Degree of Freedom & Prob. \\
\hline LDP & 0.987689 & 2 & 0.6103 \\
\hline \multicolumn{3}{|c|}{ Dependent Variable: LIR } & \\
\hline Excluded & Chi-Square Value & Degree of Freedom & Prob. \\
\hline LDP & 2.156217 & 2 & 0.3402 \\
\hline \multicolumn{3}{|c|}{ Dependent Variable: LCPI } & \\
\hline Excluded & Chi-Square Value & Degree of Freedom & Prob. \\
\hline LDP & 6.76035 & 2 & 0.0340 \\
\hline
\end{tabular}

Note: Hypothesis tests were based on a significance level of 0.01 (1\%), 0.05 (5\%) and 0.1 (10\%).

Table 13 shows the results of VAR Granger causality / Block Exogeneity Wald test to analyze the causality relation between the variables for Model 1. Findings of the study reveal that the domestic number of passengers (LDP) and the consumer price index (LCPI) are Granger's cause at the level of $5 \%$ significance.

Table 14: Granger Causality/Block exogeneity wald test for model 2

Sample: 19832015

Number of Observations: 32

Dependent Variable: LIP

\begin{tabular}{|c|c|c|c|}
\hline Excluded & Chi-Square Value & Degree of Freedom & Prob. \\
\hline LGDP & 0.334038 & 1 & 0.5633 \\
\hline LIR & 0.365288 & 1 & 0.5456 \\
\hline $\mathrm{LCPI}$ & 0.384815 & 1 & 0.5350 \\
\hline All & 1.374938 & 3 & 0.7114 \\
\hline \multicolumn{4}{|c|}{ Dependent Variable: LGDP } \\
\hline Excluded & Chi-Square Value & Degree of Freedom & Prob. \\
\hline LIP & 0.046439 & 1 & 0.8294 \\
\hline \multicolumn{4}{|c|}{ Dependent Variable: LIR } \\
\hline Excluded & Chi-Square Value & Degree of Freedom & Prob. \\
\hline LIP & 1.021769 & 1 & 0.3121 \\
\hline \multicolumn{4}{|c|}{ Dependent Variable: LCPI } \\
\hline Excluded & Chi-Square Value & Degree of Freedom & Prob. \\
\hline LIP & 1.033036 & 1 & 0.3094 \\
\hline
\end{tabular}

Note: Hypothesis tests were based on a significance level of $0.01(1 \%), 0.05(5 \%)$ and $0.1(10 \%)$.

Table 14 shows the results of the VAR Granger causality / Block Exogeneity Wald test to analyze the causality relation between the variables for Model 2 . The results of the analysis show that there is no Granger causality relation between the variables at the level of $10 \%$ significance for Model 2. 
Table 15: Granger Causality/Block exogeneity wald test for model 3

\begin{tabular}{|c|c|c|c|}
\hline \multicolumn{2}{|c|}{ Sample: 19832015} & & \\
\hline \multicolumn{3}{|c|}{ Number of Observations: 31} & \\
\hline \multicolumn{3}{|c|}{ Dependent Variable: LIC } & \\
\hline Excluded & Chi-Square Value & Degree of Freedom & Prob. \\
\hline LGDP & 3.739732 & 2 & 0.1541 \\
\hline LFTV & 0.795481 & 2 & 0.6718 \\
\hline LIPI & 2.886191 & 2 & 0.2362 \\
\hline LDFI & 0.250267 & 2 & 0.8824 \\
\hline All & 6.051611 & 8 & 0.6415 \\
\hline \multicolumn{4}{|c|}{ Dependent variable: LGDP } \\
\hline Excluded & Chi-Square Value & Degree of Freedom & Prob. \\
\hline LIC & 1.319072 & 2 & 0.5171 \\
\hline \multicolumn{4}{|c|}{ Dependent variable: LFTV } \\
\hline Excluded & Chi-Square Value & Degree of Freedom & Prob. \\
\hline LIC & 0.727388 & 2 & 0.6951 \\
\hline \multicolumn{4}{|c|}{ Dependent variable: LIPI } \\
\hline Excluded & Chi-Square Value & Degree of Freedom & Prob. \\
\hline LIC & 0.212041 & 2 & 0.8994 \\
\hline \multicolumn{4}{|c|}{ Dependent variable: LDFI } \\
\hline Excluded & Chi-Square Value & Degree of Freedom & Prob. \\
\hline LIC & 0.706152 & 2 & 0.7025 \\
\hline
\end{tabular}

Note: Hypothesis tests were based on a significance level of $0.01(1 \%), 0.05(5 \%)$ and $0.1(10 \%)$

Table 15 presents the results of the VAR Granger causality / Block Exogeneity Wald test to analyze the causality relationship between variables for Model 3 . The results of the analysis show that there is no Granger causality relation between the variables with $10 \%$ significance level for Model 3.

\section{Conclusion}

A review of the historical development of the air transport in Turkey shows that, with the Civil Aviation Law No. 2920 adopted in 1983, the legislation banning the private enterprises from operating in the aviation industry was removed, which has increased the competition in Turkish aviation sector and expanded it beyond its limited scope of performing only state-owned operations. After this initiative, the air transport industry has adopted a structure that is open to both national and global developments and improvements. Therefore, it has become crucial to ascertain empirically whether the macroeconomic variables have an effect on air transport in Turkey, and if affirmative, what its exact direction and strength is. Essentially, this study aims to find out the precise nature of the relationship between the macroeconomic factors and the air transport variables in Turkey.

Three different measurement indicators of air transport determinants were used in this study. These are the number of domestic passengers, the number of international passengers, and the amount of international cargo. For each variable for air transport, a different model was created. Thus, three different models were used including the macroeconomic determinants of the number of domestic passengers, the number of international passengers, and the amount of international cargo. The macroeconomic variables used in the models were adopted from the relevant research literature. 
The data from the 1983-2015 period were analyzed by using the VAR analysis method. To calculate any changes in the variables as a response to a shock in a variable, the Impulse-Response analysis was used. The variance decomposition analysis was performed on a yearly basis to see the effect of each of the variables resulting from both their own shocks and the shocks of the other variables. Finally, the Granger causality analysis was employed to determine the existence of a lagged relationship between variables, and to investigate the cause-effect relationships between the variables.

The Impulse-Response analysis results show that the number of domestic passengers increases from the second period and this increase continues until the fourth period, and as a result of a shock in the number of domestic passengers, income per capita is positive for the first two periods, and returns to normal after being negatively affected in the subsequent periods. Furthermore, the findings indicate that due to a shock in the consumer price index, the number of domestic passengers is affected negatively from the first period onward, and this effect continues until the end of the fourth period.

The Impulse-Response analysis results further demonstrate that the gross domestic product (GDP) variable is positively affected by a shock in the number of international passengers, and this effect returns to normal after one period. Moreover, triggered by a shock in the number of international passengers, the interest rate increases from the first period and this effect returns to normal in the third period. Due to a shock in the consumer price index, the number of international passengers decreases until the second period and then this effect disappears.

According to Impulse-Response analysis, as a result of a shock in the gross domestic product (GDP) variable, international cargo amount is negatively affected in the short-term, and positively affected in the subsequent periods. The results show that a shock coming from the industrial production index affects the international cargo amount positively until the end of the second period and negatively in the third period, and as a result of a shock in the foreign trade volume, the amount of international cargo is positively affected.

Another analysis used in the study is the analysis of variance decomposition. The results of this analysis indicate that the changes in the domestic passenger (LDP) variable affect the per capita income and consumer interest rate (LCPI) variables. According to this, approximately $9 \%$ of the change in the domestic passenger variable is determined by the per capita income and $8,3 \%$ by the consumer price index (LCPI). When the results for the number of international passengers (LIP) are examined, it is clear that approximately $3 \%$ of the changes are determined by the gross domestic product (LGDP), and $2.3 \%$ by the consumer price index (LCPI). Finally, the variance decomposition analysis results for the international cargo (LIC) variable show that starting from the third period, changes in the international cargo variable are influenced by the gross domestic product (LGDP) and industrial production index (LIPI) variables. Accordingly, for the third period, $78.5 \%$ of the change in the international cargo variable is explained by itself, $11.5 \%$ is explained by the gross domestic product (LGDP) and $8 \%$ is explained by the industrial production index (LIPI).

The final analysis performed in this study is the Granger causality analysis. The analysis results for the purpose of examining the lag correlations and causal relationships between the variables show that at a level of significance of $10 \%$, there is no Granger causality relationship in a significant number of the variables. The Granger causality relationship was only established towards the consumer price index from the number of domestic passengers. According to this finding, at the level of 5\% significance, the number of domestic passengers is the Granger cause of consumer price index (CPI). 
Overall, in Turkey, regarding the macroeconomic factors with an impact on the variables related to air transport, per capita income, gross domestic product (GDP), and consumer price index variables are significantly influential on the number of domestic and international passengers. This supports the proposition that the biggest factor affecting/determining air transport is income. When the factors affecting the international cargo amount are examined, it is evident that the gross domestic product (GDP) variable is in a decisive position. Therefore, it can be assumed that the changes in the gross domestic product and industrial production index variables have a decisive influence on the air cargo transport.

The models created by future studies may include some other variables that were not part of the current study, and thus by providing a deeper analysis of the relationships between the variables, they can make a further contribution to the air transport literature. Additionally, based on the models of the present study, the situation in Turkey can be compared to that of other countries to reveal the similarities and discrepancies among various countries, enabling a more comprehensive analysis from a broader perspective.

\section{References}

Abed, S. Y., Ba-Fail, A. O., \& Jasimuddin, S. M. (2001). An econometric analysis of international air travel demand in Saudi Arabia. Journal of Air Transport Management, 143-148.

Aderamo, A. J. (2010). Demand for Air Transport in Nigeria. Journal of Economics, 1(1), 23-31.

Adrangi, B., Chatrath, A., \& Raffiee, K. (2001). The demand for US air transport service: a chaos and nonlinearity investigation. Transportation Research Part E: Logistics and Transportation Review, 37(5), 337-353.

Ba-Fail, A. O., Abed, S. Y., \& Jasimuddin, S. M. (2000). The Determinants of Domestic Air Travel Demand in The Kingdom Of Saudi Arabia. Journal of Air Transportation World Wide, 5(2), 72-86.

Baikgaki, O. A., \& Daw, O. D. (2013). The Determinants of Domestic Air Passenger Demand in the Republic of South Africa. Mediterranean Journal of Social Sciences, 4(13), 389-396.

Baker, D., Merkert, R., \& Kamruzzaman, M. (2015). Regional aviation and economic growth: cointegration and causality analysis in Australia. Journal of Transport Geography, 43, 140-150.

Bakırc1, M. (2012). Ulaşım coğrafyası açısından Türkiye'de havayolu ulaşımının tarihsel gelişimi ve mevcut yapısı. Marmara Coğrafya Dergisi, 1(25), 340 - 377.

Banister, D., \& Berechman, Y. (2001). Transport investment and the promotion of economic growth. Journal of transport geography, 9(3), 209-218.

Berm'udez, J. D., Segura, J. V., \& Vercher, E. (2007). Holt-Winters forecasting: an alternative formulation applied to UK air passenger data. Journal of Applied Statistics, 34(9), 1075-1090.

Beyzatlar, M. A., M. K., \& Yetkiner, H. (2014). Granger-causality between transportation and GDP: A panel data approach. Transportation Research Part A(63), 43-55.

Brons, M., Pels, E., Nijkamp, P., \& Rietveld, P. (2002). Price elasticities of demand for passenger air travel: a meta-analysis. Journal of Air Transport Management, 8(1), $165-175$.

Brueckner, J. K. (2003). Airline Traffic and Urban Economic Development. Urban Studies, 40(8), 1455-1469.

Button, K., \& Yuan, J. (2013). Airfreight Transport and Economic Development: An Examination of Causality. Urban Studies, 50(2), 329-340. 
Chi, J., \& Baek, J. (2013). Dynamic relationship between air transport demand and economic growth in the United States: A new look. Transport Policy(29), 257-260.

Doğan, E. M., Akan, Y., \& Oktay, E. (2006). Şehirlerarası Ulaşım Talebini Etkileyen Faktörlerin Analizi: Atatürk Üniversitesi Öğrencileri Üzerine Bir Uygulama. Atatürk Üniversitesi Sosyal Bilimler Enstitüsü Dergisi, 7(1), 345-356.

Erraitab, E. (2016). An Econometric Analysis Of Air Travel Demand: The Moroccan Case. European Scientific Journal, 12(7), 167-380.

Erraitab, E., Hefnaoui, A., \& M. M. (2016). A Cointegration Analysis of Air Travel Demand: The Case of International Air Travel Demand between Morocco and European Union. International Journal for Traffic and Transport Engineering, 6(1), 104-120.

Fernandes, E., \& Pacheco, R. R. (2010). The causal relationship between GDP and domestic air passenger traffic in Brazil. Transportation Planning and Technology, 33(7), 569581.

Fuellhart, K., \& O'connor, K. (2013). Air Services at Australian Cities: Change and Inertia 2005-2010. Geographical Research, 51(1), 37-48.

Granèay, M. (2010). The Economic Impacts of Air Transport Liberalization. Zagreb International Review of Economics \& Business, 13(2), 73-88.

Grubba, H., \& Mason, A. (2001). Long lead-time forecasting of UK air passengers by HoltWinters methods with damped trend. International Journal of Forecasting, 17(1), 7182.

Hakim, M. M., \& Merkert, R. (2016). The causal relationship between air transport and economic growth: Empirical evidence from South Asia. Journal of Transport Geography (56), 120-127.

Hensher, D. A., Truong, T. P., Mulley, C., \& Ellison, R. (2012). Assessing the wider economy impacts of transport infrastructure investment with an illustrative application to the North-West Rail Link project in Sydney, Australia. Journal of Transport Geography, 24(1), 292-305.

Hu, Y., Xiao, J., Deng, Y., Xiao, Y., \& Wang, S. (2015). Domestic air passenger traffic and economic growth in China: Evidence from heterogeneous panel models. Journal of Air Transport Management (42), 95-100.

IATA. (2016). Air Freight Market Analysis-June 2016. The International Air Transport Association (IATA).

Ishutkina, M. A., \& Hansman, R. J. (2008). Analysis of Interaction between Air Transportation and Economic Activity. The 26th Congress of International Council of the Aeronautical Sciences (ICAS). Alaska.

Itoa, H., \& Lee, D. (2005). Assessing the impact of the September 11 terrorist attacks on U.S. airline demand. Journal of Economics and Business, 57(1), 75-95.

Kasarda, J. D., \& Green, J. D. (2005). Air cargo as an economic development engine: A note on opportunities and constraints. Journal of Air Transport Management, 11(1), 459462.

Kiboi, J. W., Katuse, P., \& Mosoti, Z. (2017). Macroeconomic Determinants of Demand for Air Passenger Transport Among Selected Airlines. Journal of Business and Strategic Management, 2(3), 101-118.

Kopsch, F. (2012). A demand model for domestic air travel in Sweden. Journal of Air Transport Management, 20(1), 46-48.

Kulendran, N., \& Wilson, K. (2000). Is there a relationship between international trade and international travel? Applied Economics, 32(8), 1001-1009.

Kupfer, F., Meersman, H., Onghena, E., \& Voorde, E. V. (2009). Air Cargo: The Difference between Success and Failure? European Transport Conference (1-31). Association for European Transport and contributors. 
Lai, S. L., \& Lu, W.-L. (2005). Impact analysis of September 11 on air travel demand in the USA. Journal of Air Transport Management, 11(1), 455-458.

Marazzo, M., Scherre, R., \& Fernandes, E. (2010). Air transport demand and economic growth in Brazil: A time series analysis. Transportation Research Part E (46), 261269.

Ozan, C., Başkan, Ö., Haldenbilen, S., \& Ceylan, H. (2014). Yurtiçi hava taşımacılığı talebinin modellenmesi ve senaryolar altında değerlendirilmesi. Pamukkale Üniversitesi Mühendislik Bilimleri Dergisi, 29(9), 319-323.

Profillidis, V., \& Botzoris, G. (2015). Air passenger transport and economic activity. Journal of Air Transport Management (49), 23-27.

Sevüktekin, M., \& Çınar, M. (2014). Ekonometrik Zaman Serileri Analizi. DORA BasımYayın ve Dağıtım Ltd. Şti.

Sivrikaya, O., \& Tunç, E. (2013). Demand Forecasting for Domestic Air Transportation in Turkey. The Open Transportation Journal, 7, 20-26.

Sofany, A. (2016). The Determinants Of Domestic Air Transport Demand In Ethiopia. Addis Ababa: Addis Ababa University, The Department of Economics.

Tarı, R. (2012). Ekonometri (8. Baskı b.). Kocaeli: Umuttepe Yayınları.

Tsekeris, T. (2009). Dynamic analysis of air travel demand in competitive island markets. Journal of Air Transport Management, 15(1), 267-273.

Valdes, V. (2015). Determinants of air travel demand in Middle Income Countries. Journal of Air Transport Management, 42(1), 75-84.

Vijver, E. V., Derudder, B., \& Witlox, F. (2014). Exploring causality in trade and air passenger travel relationships: the case of Asia-Pacific, 1980-2010. Journal of Transport Geography, 34(1), 142-150.

Xiao, Y., Liu, J. J., Hu, Y., Wang, Y., Lai, K. K., \& Wang, S. (2014). A neuro-fuzzy combination model based on singular spectrum analysis for air transport demand forecasting. Journal of Air Transport Management, 39(1), 1-11.

Yao, V. W. (2005). The causal linkages between freight and economic fluctuations. International Journal of Transport Economics, 32(2), 143-159.

Yılmaz, Ö., \& Kaya, V. (2007). İhracat, ithalat ve reel döviz kuru ilişkisi: Türkiye için bir VAR modeli. İktisat Işletme ve Finans, 22(250), 69-84. 